\title{
The Performance of Lecturer in the Development of Academic Culture in Ilmu Tarbiyah Al-Hilal College of Sigli
}

\author{
Sulaiman $^{1}$, Fuad $^{2}$, Muhammad Iqbal $^{3}$, Muhammad $^{4}$ \\ ${ }^{1}$ Lecturer in Jabal Ghafur Univerisity, Indonesia. \\ ${ }^{2,3}$ Lecturer in Al-Hilal Collage, Sigli, Indonesia \\ ${ }^{4}$ Norwegian Citizens \\ Sulaimanusman1959@gmail.com
}

\begin{abstract}
Ilmu Tarbiyah Al-Hilal College of Sigli is an institution of higher education and a center for strategic study of Islamic religious knowledge that requiring lecturers who have the ability and reliable performance. This study is aimed to determine the performance of lecturer at the Tarbiyah Al-Hilal Sigli College of Sciences. This study uses a descriptive approach and qualitative methods with data collection techniques used were documentation, observation and interviews. Research subjects were College chairpersons, study program chairpersons, lecturers, administrative chairpersons, and students. Data analysis were performed by: data reduction, data presentation, and drawing conclusions. This research shows that: 1) the performance of lecturers in conducting the learning process has followed the principles of learning, this is seen from the planning, implementation and evaluation of learning carried out by lecturers. 2) The motivation of lecturers in conducting the learning process is reflected in the willingness and awareness of lecturers in carrying out the tasks assigned to them.
\end{abstract}

Keywords: Performance; lecturer; academic culture.

\section{Introduction}

Education is a conscious effort made by adults for human maturity which is carried out in the process of teaching and learning activities, both formally and informally. Education is expected to be able to answer all the challenges of the times and be able to foster national generations, so that people become reliable and of high quality, with strong characteristics, clear identities and able to deal with current and future problems.

Al-Hilal Islamic University of Sigli is an institution of higher education that seeks to be a center for strategic study of Islamic religious knowledge that is preparing students to become members of the community who have professional academic abilities, able to develop, disseminate and practice better Islamic religious knowledge. To implement the educational functions in tertiary institutions, educators are needed who have good educational qualifications and competencies. "Law on the National Education System Number 20/2003 of the Teachers and Lecturers Law Number 14/2005, requires minimum university lecturers, in the Law it is mentioned, educators at the elementary and secondary education levels must have a minimum S1 degree. Meanwhile, to educate at the undergraduate academic level, at least a bachelor degree (S2) is held. Whereas for Postgraduate the academic requirements of teaching staff are doctors (S3) and professors (Sanjaya, Vienna: 2010).

Lecturers must have some qualifications needed for the implementation of their profession, considering that the teaching profession is different from other professions. In addition to knowledge, lecturers must also be able to convey their knowledge to students. With lecturers who are motivated, competent and qualified will facilitate the delivery of science and technology so that what is conveyed to students can be accepted and developed according to students' abilities with the study of the chosen field of science. Besides that lecturers must also have a high commitment which is indicated by attendance at work time, 
also has a sense of responsibility towards the knowledge given to students. Sukirno, (2013) in his journal said that lecturer performance in higher education becomes a prominent element in coloring university performance and has been an interesting and important issue in educational studies.

To implement the lecturer duties effectively and efficiently the lecturers are required to have abilities in accordance with the field of science, as academics are responsible for the continuity of education in tertiary institutions, especially in the process of learning at Ilmu Tarbiyah Al-Hilal College of Sigli and lecturers must be able implements their duties optimally Usman (2012) states that competence is the ability to describe the suitability of each individual in carrying out the task. Competence is an important factor for individuals, because individuals who have competence will be able to display the quality and productivity of work in carrying out an activity. Competence shows behavior that enables them to carry out tasks in the most desirable way and not just carry out routine activities.

The abilities and skills possessed by lecturers must always be developed to improve lecturer performance in tertiary institutions. So that human resources as graduates from higher education institutions that will enter the middle of society will be able to apply their knowledge and skills well.

Lecturers must always develop innovative and inventive works that can be achieved through research activities and community service. As a consequence of the profession of lecturers in their fields, the lecturer must be able to reach the level of ability in his field of science which is his responsibility. This is in accordance with the opinion of Usman, (2012) said that an educator should have a solid performance competency that is a set of mastery abilities that must be present in him in order to realize performance appropriately and effectively.

Discipline and awareness of lecturers on the implementation of the task has not reached the specified target. The commitment of lecturers in implementing their duties as teaching staff has not been reflected in their behavior, the workload provided cannot yet be carried out with full responsibility. Therefore, the assessment of a lecturer's work performance can be seen from their discipline in implementing the duties and responsibilities of the work that has been charged to them in accordance with the division of teaching assignments in each semester of the academic year. The quality of lecturer performance at Ilmu Tarbiyah College is a factor that must be improved so that quality and developing educational institutions.

\section{Research Method}

The method is a way or path taken in conducting research. In this study the researchers used descriptive research. Descriptive is to focus attention on the phenomena that occur at this time through efforts to make a description of the phenomenon under investigation, by describing and classifying facts or characteristics of the phenomenon factually and accurately.

Based on the issues raised by the researchers, the type of research used in this study is a qualitative descriptive study that aims to see the reality, circumstances and facts that have been and are developing. In this study, researchers collected data in the form of descriptions that have nuances of description, about the activities, or subjects to be studied, both regarding perceptions, and other things found through interviews, observations and documentation. The selection of this method is based on the consideration that what is being sought is data that 
will provide a picture and describe a concrete social reality about the performance of lecturers at Ilmu Tarbiyah Al-Hilal College of Sigli.

This study is aimed to determine the performance of lecturers at Ilmu Tarbiyah Al-Hilal College of Sigli which includes: ability, motivation, commitment and discipline in implementing their duties as educators. The results of the study are presented naturally according to what is happening in the field. Therefore, this research is in the form of descriptive research by explaining naturally the facts found in the field about the performance of lecturers at Ilmu Tarbiyah Al-Hilal College of Sigli.

\section{Discussion}

Based on the results of the study, lecturers wanted the lecturers' performance related to development. Of course the institution must really realize this desire, in addition because it is in accordance with the wishes of the lecturer, it is also relevant to theories that develop about personnel performance not only for the sake of assessing the extent to which lecturer performance has been implemented according to standards but the results are used for development career through activities: 1) the ability in conducting the learning process, such as (a) planning, (b) implementation, and (c) learning evaluation, 2) lecturer motivation in conducting the learning process, 3) lecturer discipline in conducting the learning process, 4) commitment and responsibility answered the lecturer in conducting the learning process.

\subsection{The Competence of Lecturers in Conducting the Learning Process}

\section{a. Lecture Planning}

Lecture planning is a preparation that must be done, and is the first step that must be done by lecturers is to prepare a plan by preparing lecture planning in accordance with the courses they are taking care of that is by preparing a variety of recovery tools, such as: preparation of Learning process Event Unit, preparation the learning material, and planning related to learning assessment system. The planning compiled by lecturers pays attention to the basic competency demands of each course, achievement indicators, learning process activity scenarios, organizing learning materials, media and learning resources, organizing time, and planning learning assessment systems, reviewing the curriculum by preparing syllabus, this is intended to maintain appropriateness between the applicable curriculum with the conditions and development of students.

Lecturers prepare for planning by preparing the learning process planning in accordance with the courses they care for that is by preparing a variety of recovery tools, such as: preparation of Learning process Event Unit, preparation the learning material, and planning related to learning assessment system. The planning compiled by lecturers pays attention to the basic competency demands of each course, achievement indicators, learning process activity scenarios, organizing learning materials, media and learning resources, organizing time, and planning learning assessment systems.

The learning process system that is planned by the lecturer is in accordance with the field of subjects that are nurtured and in accordance with the area of their expertise, so that the division of courses given to lecturers by paying attention to the expertise and discipline of the lecturer. Because without proper appropriateness of disciplines and expertise by lecturers, the aim of education in higher education is difficult to succeed, so to become an educator 
such as lecturer must have a good scientific background through the relevant educational process, as explained by Usman.

The learning process implementation is a follow-up of the real duties of the lecturer in performing the roles of their assignment. Implementation of the learning process, if viewed from the task of the lecturer, is the core of the task, what has been planned properly must be applied well in the implementation of the assignment. Implementation of the learning process includes the use of media, methods, learning materials, demonstrating mastery of lecture materials, communicating, encouraging students and organizing time, place and course material.

The expose of data that has been described in the data description section of research results, the learning process planning is an effort made by the lecturer to formulate what is to be achieved from the learning process to be implement and adapted to the vision, mission and goals of the institution, so that the learning process planning conducted by the lecturer is arranged through development syllabus at the department level which is conducted jointly by lecturers of one department or independently. This is to ensure a good quality of education, then program planning must be planned before the learning process is implement, because the planning is an attempt at how the desired lecture can be carried out in accordance with the objectives, as explained by Usman.

Based on the results of the study, it was revealed that the lecturer developed a learning process plan to formulate the objectives and implementation of the learning process. Planning the learning process compiled by lecturers related to the learning process system that will be carried out by the lecturer later. For this reason, the first step that must be taken by lecturers is to review the curriculum by preparing a syllabus, this is intended to maintain the compatibility between the applicable curriculum with the current conditions, developments in science and technology, as explained by E. Mulyasa.

Furthermore, related to the development of the syllabus at Ilmu Tarliyah Al-Hilal College of Sigli is a necessity, as well as compiling or preparing a learning process event unit, this is related to the policy of the leadership of Ilmu Tarliyah Al-Hilal College of Sigli which tightens the readiness of the lecturers before implementing the learning process. This relates also to the policy of the Directorate General of Higher Education through the National Accreditation Board of Higher Education (BAN PT) which has the task to evaluate and monitor the activities and management of study programs or majors through the granting of study program accreditation. One of the components of accreditation assessed by BAN PT is looking at the learning process preparation documents carried out by lecturers, both syllabus documents, SAP, sample assessment instruments each semester, and lecture materials used by lecturers.

Based on the Higher Education policy in evaluating the management and implementation of the department, the leadership policy at Ilmu Tarliyah Al-Hilal College of Sigli requires that every lecturer prepare a plan related to the learning process by handing over all the documents to their respective study programs. So this policy is not only beneficial for the department in preparing study program accreditation documents and also very useful for lecturers in conducting the learning process.

Furthermore, based on the results of the study it was also revealed that, to expedite the learning process, lecturers also adapted the learning process plan to the characteristics of the learning material, through the selection of appropriate strategies, models and approach to the learning process and could help students understand the learning process material well. The 
selection of strategies, models and approaches of the learning process planned by lecturers is always sought to be carried out according to plan. This is done to plan effective and efficient the learning process, so lecturers must be creative in choosing the learning process strategies, models and approaches. These results are consistent with the theory put forward by Ngainum Naim about the learning approach process.

So planning the selection of strategies, models and approaches to the right lectures can help the learning process which helps students explore knowledge, skills, and attitudes in achieving educational goals in higher education as an educational institution.

\section{b. The Ability in Implementation of the learning process}

Based on the results of the research described in the previous section, it was revealed that in implementing the learning process, the lecturer sought that students were always required to be active in each recovery. The learning process carried out by lecturers at Ilmu Tarliyah Al-Hilal College of Sigli include learning activities in the lecture room such as lecturing, discussion, presentation of papers, and simulation / practice are activities that continue to be pursued in an effort to help students understand the learning material.

Concerning the use of strategies, approaches and methods in conducting the learning process carried out by lecturers at Ilmu Tarliyah Al-Hilal College of Sigli shows that lecturers strive to provide varied the learning process, which are adapted to the objectives of the learning process, the state of students, the state of the lecture room, so there is harmony by using a variety of strategies, approaches and methods in the learning process.

Implementation of the learning process carried out by considering the use of methods and approaches of the learning process that are relevant and varied will help lecturers to carry out the learning process that are effective and efficient, and can encourage lecturers to reflect on the learning process that have been implemented. These efforts, if carried out continuously will have a positive impact.

Based on the results of the study illustrated that, along with changes in the paradigm of the learning process in the education world so far, ranging from basic education to higher education there was a paradigm shift from lectures that were centered on lecturers to become student-centered. This paradigm change in Ilmu Tarliyah Al-Hilal College of Sigli has an effect on lecturers' strategies or approaches to students in carrying out the lecture process which emphasizes student activities through activities that enable students to learn and understand understanding of lecture material.

Furthermore, it was also revealed that the effort to change the conventional lecture paradigm to innovative lectures by lecturers at the Tarbiyah Al-Hilal Sigli College of Sciences, could not necessarily be carried out by all lecturers. It can be understood that some of the lecturers are accustomed to conducting the learning process using the discussion (ceramah) method and making lecturers the only source of learning for students. So it is difficult for lecturers who are accustomed to carrying out the learning process with the method of lecture is difficult to change to innovate the learning process.

The ability of lecturers in the implementation of the learning process can be seen through lecturers in the teaching and learning process in using methods, media and training materials that are in accordance with teaching objectives, communicating with students, applying various teaching methods, encouraging and promoting student involvement in lectures, demonstrating mastery of a lesson and its relevance, so students are active in 
learning and provide opportunities for students to actively discover and reconstruct concepts or knowledge.

Furthermore, the ability to teach lecturers is also the ability to organize time, evaluate student achievement in the learning process, which basically has been obtained since the lecturer studied at educational institutions educational staff. However, based on the results of the study also illustrated that there are also a small number of lecturers who are less interested in developing and using the learning process strategies, approaches and methods, in other words the lecturer uses the conventional the learning process model that is only using the lecture method without any innovation in conducting the learning process.

This happens because some lecturers still understand the paradigm of teaching as transmission of knowledge, where lecturers as transmission of knowledge. So the learning process carried out by lecturers assume that students are the object or target of learning. The atmosphere of the learning process like this is a description of lectures mechanistically that emphasizes the practice of working on the problem or drill by repeating the procedure and giving lectures as the only the learning process method.

In connection with the implementation of the learning process in tertiary institutions, lecturers are required to work in accordance with their role in tertiary institutions more effectively, efficiently, and to maintain the quality and quantity of work that affects the competitiveness of the institution. So that the development of the ability of lecturers as individuals who are required to follow the times.

According to Kunandar to face the era of globalization which is full of competition and uncertainty, visionary lecturers are needed and are able to manage the teaching and learning process effectively and innovatively. The ability and skills of good personnel at this time are felt to be increasingly important because of the demands or positions, as a result of advances in technology which is increasingly fierce competition between similar organizations / companies.

Furthermore, it relates to the competence of lecturers in carrying out the learning process in caring for the course, which is also assisted by other components namely facilities, infrastructure and other infrastructure. Lecturers become an important factor in relation to the implementation of coaching, development and decision making in order to realize the vision, mission of the tertiary institution, besides it can also be used as an open performance appraisal that refers to the triadarma of tertiary institutions, in accordance with the provisions of the Higher Education that.

Lecturers must always develop innovative and creative works that can be achieved through a series of research activities and community service. As a consequence of the professionalism of a lecturer in his field, the lecturer must be able to reach the level of competence in the field of science for which he is responsible.

Based on the results of the study, it was also revealed that to improve the quality of the learning process carried out by lecturers, the lecturer also develops his knowledge, and follows the development of current science. Lecturer efforts in developing knowledge can be done through research, which can then be used as discussion material and learning material to improve student competency. Furthermore, in the implementation of the learning process, lecturers are required to interact more with students to provide guidance and direction for students who experience difficulties. The lecturer as an educator acts as a mediator and facilitator who helps the teaching and learning process run well. Therefore the lecturer becomes an active partner and stimulates student thinking. 
The process of constructing knowledge experienced by students needs guidance from the lecturer. Therefore, lecturers must be able to design the learning process in such a way that students can build their own understanding through lecture activities designed by the lecturer. An important activity in the learning process is to provide interpretation through schemata owned by students. Students are given the opportunity to construct their own knowledge. The role of lecturers as educators in the learning process is to facilitate students to construct knowledge in accordance with the schema and initial knowledge.

Then in the final stage of the learning process the lecturer closes the learning process by making a conclusion. The importance of making conclusions at the end of the learning process, activities summarizing and drawing conclusions can be done by students under the guidance of lecturers / teachers, or students with teachers. The activity of making conclusions will strengthen the material that has been studied by students. Furthermore, with the consideration of insufficient time, all research subjects did not carry out the final lecture tests that should have been made to convince lecturers that students had reached the level of mastery learning.

\section{c. The Ability in Evaluating the Learning Process}

Evaluation is an inseparable part of the teaching and learning process, evaluation is an identification activity to see whether an activity that has been planned has been achieved or not, valuable or not, and can also to see the level of efficiency of its implementation.

At present evaluation is no longer directed towards the end of the learning process, but is a continuous process to help students achieve the goals of the learning process and obtain minimal competence. So that each assessment is expected to have a follow-up program, which is an enrichment program for students who have completed mastery learning.

Related to the ability of lecturers to carry out the learning process evaluations is the ability to obtain complete data and information from the process and results of student learning, so that lecturers can make decisions and follow up appropriately for the development of student learning. So the evaluation is related to the decision making by the lecturer, as explained by Djamarah. So that the evaluation can be said as an identification activity to see whether a planned the learning process activity has achieved its objectives or not, and can also to see the level of efficiency of its implementation.

Based on the results of research observations revealed that, the evaluation activities carried out by lecturers at Ilmu Tarbiyah Al-Hilal College of Sigli is an effort to gather information on student learning outcomes, the selection of appropriate methods and tools by lecturers adjusted to the characteristics of recovery materials and carried out carefully, because not all lecturers can gather appropriate information about student learning outcomes. Furthermore, the research data also shows that the learning process evaluation activities carried out by lecturers are used to assess the progress and success of students at Ilmu Tarbiyah Al-Hilal College of Sigli through consideration of the ability to answer questions both verbally and in writing at the beginning of the semester quiz, midterm in the middle of the semester and finals at the end of the semester as well as exercises and work on independent / group assignments.

The evaluation carried out by lecturers at Ilmu Tarbiyah Al-Hilal College of Sigli is directed no longer to be the final process of the learning process, but is a continuous process to help students achieve the goals of the learning process and obtain minimal competence, so 
as to know the development progress of student learning, and can be pursued improving the implementation of the learning process to improve student understanding.

Based on the results of the study it was revealed that the lecturer used the data from the quiz test, and the midterm exam, and also the final exam at the end of each semester to determine the level of student achievement in attending the learning process. Furthermore, the lecturer also analyzes the results of the evaluation to obtain complete data for the lecturer to take an attitude towards the next lecture process, as explained by Munthe.

Furthermore, based on the results of the study also showed that in carrying out the learning process evaluations, lecturers set the learning process objectives which are then broken down into indicators, so that lecturers can determine invoices to students through assessment instruments using either written test or oral tests. Furthermore, it can be illustrated that the policy of the leadership of Ilmu Tarbiyah Al-Hilal College of Sigli encourages lecturers to develop an evaluation tool by considering evaluation techniques developed in accordance with the academic manuals owned by Ilmu Tarbiyah Al-Hilal College of Sigli.

In accordance with the guidelines for conducting evaluations in Ilmu Tarbiyah Al-Hilal College of Sigli, lecturers are advised to use various assessments or other forms of assessment in addition to written test assessments, as one way to complete data / information about the development of student learning outcomes. Lecturers are expected to develop alternative assessment systems, this is in line with Munthe's opinion. This is based on the assessment of student learning outcomes closely related to the assessment of the lecture process itself. So the lecturer must monitor and monitor the progress of student learning in conducting lectures in order to get information or data on student development.

\subsection{Motivation of Lecturers in Conducting the Learning Process}

Then, as previously explained that related to the motivation of lecturers in conducting the learning process is greatly influenced by the willingness and awareness factors of lecturers themselves in carrying out effective and efficient the learning process, as explained by Usman, Husaini. It is also influenced by income or welfare, facilities / infrastructure, and a sense of comfort, harmony and a pleasant atmosphere, so that the lecturers are motivated to work optimally while working.

Based on the results of the study relating to the motivation of lecturers in conducting the learning process is strongly affected by the willingness and awareness of the lecturers themselves in carrying out effective and efficient lectures. It is also influenced by income or welfare, facilities / infrastructure, and a sense of comfort, harmony and a pleasant atmosphere in the work environment. Furthermore, related to welfare, it was revealed that income or welfare affected the performance of lecturers in carrying out their duties and obligations, so that many lecturers were active off campus, both teaching at private universities, becoming consultants, active in NGOs and others. So thus that the motivation of lecturers in carrying out their duties and responsibilities, salary and welfare of lecturers greatly influences, this is in accordance with the opinion of Al-Abrasyi in his interpretation. Because the lecturer / teacher's job is a noble job and has a good social stratum in the community so that although the current welfare is not so good, the reality does not significantly reduce the lecturer's performance.

Furthermore, other factors that can balance the motivation of lecturers at this time, so that although the welfare of lecturers cannot be said to be good, but a conducive climate can increase the motivation of lecturers at work. The results of the study, showed that related to 
lecturers 'motivation in improving lecturer performance, based on the results of the study showed that the uncomfortable conditions in Ilmu Tarbiyah Al-Hilal College of Sigli could make lecturers' work motivation decrease, because the lecturers felt uncomfortable and calm being on campus, so that relations appear less friendly conditions and the lack of kinship that appears among campus residents, starting from the leaders of Ilmu Tarbiyah Al-Hilal College of Sigli, lecturers, students and administrative staff.

\section{Conclusion}

The performance of lecturers in carrying out the learning process has followed the principles of learning, this is seen from the learning planning made by the lecturer. Furthermore, the learning process implementation refers to the learning program unit that has been prepared and pay attention to the suitability between the materials, strategies, and methods used, as well as the learning process evaluations carried out by lecturers structured through oral and written tests, both in the quiz exam at the beginning of the semester, midterm (UTS) and final exams at the end of the semester.

The ability of lecturers to carry out the learning process evaluations is the ability to obtain complete data and information from the learning process that has been carried out by lecturers to the end, this is an activity to determine the extent to which students can absorb and understand learning material well, and lecturers will also get information on difficulties and obstacles of students in the learning process, so that decisions and appropriate follow-up can be taken to improve student understanding.

Motivation of lecturers in carrying out the learning process, based on research findings shows that conducive conditions in the work environment can make lecturer work motivation increase, because lecturers feel comfortable and calm on campus, family relationships really need to be built so that it seems friendly and harmonious among campus residents, starting from the leadership of Ilmu Tarbiyah Al-Hilal College of Sigli, lecturers, students, employees and office workers. This kind of situation causes the lecturer to feel safe, secure, and free from all pressures that can harm the learning process activities.

\section{References}

Presinden Republik Indonesia. (2005). Undang-Undang Nomor 14 2005, tentang Guru dan Dosen. Jakarta: Sinar Grafika.

Sanjaya, W. (2010). Perencanaan dan Desain Sistem Pembelajran, Jakarta: Kencana. . Sukirno. (2013). A Protrait Participation In Decision Making Among Accounting Lectures In Yogyakarta. Cakrawala Pendidikan, Th. XXXII, No. 3.

Ilham, M., Rusgiyono, A., Mukid, M., A. (2014). Penilaian Cara Mengajar Menggunakan Rancangan Acak Lengkap (Studi Kasus: Cara Mengajar Dosen Jurusan Statistika Undip), Jurnal Gaussian, Volume 3, Nomor 2, Tahun 2014.

Nasir, U. (2012). Manajemen Peningkatan Mutu Kinerja Guru, Konsep, Tiori dan Model, Bandung: Citapustaka Media Perintis. 